\title{
Determining the Influence of the Processing Temperature by Injection and of the Subsequent Pressure on the Surface's Hardness and Indentation Modulus of the Products Made of HDPE, PMMA, PC+ ABS through Nanoindentation - G-Series Basic Hardness Modulus at a Depth Method
}

\begin{abstract}
GHEORGHE RADU EMIL MARIES*, DAN CHIRA, CONSTANTIN BUNGAU, TRAIAN COSTEA, LIVIU MOLDOVAN
University of Oradea, 1 Universitatii Str., 410087, Oradea, Romania

The first part of the paper presents the influence of the processing temperature by injection of HDPE, of $P M M A$, and $P C+A B S$ blend on the indentation hardness and on the indentation modulus, when other factors that can influence the injection remain unchanged. The second part of the paper presents the influence of subsequent pressure by injection of HDPE, PMMA, and PC+ABS blend on the indentation hardness and on the indentation modulus, when the other factors remain unchanged. The HDPE samples were obtained at the following injection temperatures: $180,190,200,210$, and $220^{\circ} \mathrm{C}$, and at the following subsequent pressures: 800 bar, 900 bar, 1000 bar, 1100 bar, and 1200 bar. The PMMA samples were obtained at the following injection temperatures: $220,230,240,250$, and $260^{\circ} \mathrm{C}$, and at the following subsequent pressures: 450, 550, 650, 750, and 850 bar. The $P C+A B S$ samples were obtained at the following injection temperatures: $230,240,250,260$, and $270^{\circ} \mathrm{C}$, and at the following subsequent pressures: 500 bar, 600 bar, 700,800 , and 900 bar. The G-Series Basic Hardness Modulus at a Depth method was used to obtain the indentation hardness and the indentation modulus. It was observed that by increasing the processing temperature and subsequent pressure, in the case of HDPE, leads to an increase in indentation hardness and in indentation modulus. It was observed that increasing the processing temperature by injection in the case of PMMA, from 220 to $250^{\circ} \mathrm{C}$, leads to a slightincrease in indentation hardness and in indentation modulus, whereas increasing the subsequent pressure of PMMA, from 450 bar to 850 bar, leads to a slight decrease in indentation hardness and in the indentation modulus. Increasing the processing temperature by injection in the case of $P C+A B S$, from 230 to $250^{\circ} \mathrm{C}$, leads to a slight increase in indentation hardness and in indentation modulus. By further increasing the processing temperature by injection, from 250 to $270^{\circ} \mathrm{C}$, leads to a decrease in indentation hardness and in the indentation modulus. Alternatively, increasing the subsequent pressure from 500 bar to 900 bar leads to not only a decrease in indentation hardness but also to a decrease in the indentation modulus.
\end{abstract}

Keywords: high density polyethylene (HDPE), polymethyl methacrylate (PMMA), acrylonitrile butadiene styrene polycarbonate blend ( $P C+A B S)$, indentation hardness, indentation modulus.

The packaging industry, automotive industry, electrotechnics and electronics industry, office equipment industry, medical industry, household appliances industry, gaming and toys, aeronautics, optics and photography gear, mobile phone industry, etc, are some great consumers of plastics. The techno-polymers frequently used in the manufacturing of various components in these industries are: polyethylene, polypropylene, polycarbonates, polyamides, thermoplastic polyurethanes, polyoxymethylenes, polymethyl methacrylate, cellulose acetate, polyvinyl chloride, acrylonitrile butadiene styrene, etc. The most frequently used processing technology for these polymers is injection. The main factors that determine the manufacturing process of thermoplastic materials are: chemical, physical, and flow properties in conditions peculiar to the process of injection, temperature regimen, pressure regimen, and the necessary time for formation. The characteristics of the products obtained by the injection of thermoplastic materials are influenced by the aforementioned factors and they have been recently presented in several papers [1-6]. In recent years, a series of studies concerning the mechanical behavior of various types of polymers under different conditions has been published [7-19, 26]. Many of the products made using these materials are exposed to wear and tear by friction, especially on their surface. High-density polyethylene is one of the most frequently used techno-polymers in the manufacturing of products prone to friction. Usage: packaging industry (packing cases, foil trails, various types of shuttles, containers), household articles (bowls, cups, buckets, washtubs, food containers), toys (car body, wheels), medical items (hip prosthesis) [20]. Polymethyl methacrylate is an amorphous polymer with a remarkable transparency, which at the ambient temperature, is a hard material, rigid, resistant to aging and to atmospheric agents, with a good dimensional stability. Usage: automotive industry (windscreens, car stops, retro reflectors, dome lights, signaling lamps, dials for dashboards) [21], constructions (arched roofs), aeronautical industry, mobile phone displays, camera lenses, optics (magnifying glass, precision pieces), watches, modern furniture, plates for windows, domes, 
office equipment (squares, rulers), naval industry (portholes on ships and watercrafts), etc. The polycarbonate and acrylonitrile butadiene styrene blend is amorphous, opaque, rigid and highly resistant to shock [22]. It is resistant to wear and tear, to breaking; it has a good dimensional stability in a broad range of temperatures, unlimited possibilities for coloring, easily moldable by injection. Usage: automotive industry (rear-view mirror, bumpers, roof-racks, etc) [23], household appliances (carcasses for blow-dryers, mixers), office equipment (computer carcasses, copy machine carcasses, printer carcasses), etc.

This paper proposes, in the first part, to analyze the variation of indentation hardness and of indentation modulus depending on the processing temperature by injection, when the other possible influencing factors remain unchanged, for the high-density polyethylene HDPE type CABELEC XS6114, for the polycarbonate and acrylonitrile butadiene styrene blend $P C+A B S$ type CYCOLOY RESIN XCY620, and for the polymethyl methacrylate PMMA type PLEXIGLAS 8N CRYSTAL. The second part of the paper proposes to present the influence of the subsequent pressure during the formation by injection of HDPE, PMMA, and PC+ABS blend, on the indentation hardness and on the indentation modulus, when the other factors that could influence the process remain unchanged.

\section{Experimental part}

The following materials have been used in manufacturing the specimens: high-density polyethylene HDPE type CABELEC XS6114, polymethyl methacrylate PMMA type PLEXIGLAS 8N CRYSTAL, and polycarbonate and acrylonitrile butadiene styrene blend PC+ABS type CYCOLOY RESIN XCY620, using an injection machine, KRAUSS MAFFEI KM65-160C1, made in 2001.

Were injected and tested a total of 10 specimens of each type of material under established temperature and pressure.

The first part of the experiment focused on the influence of the processing temperature by injection on the indentation hardness and indentation modulus. Measuring the temperature in its flow state was done with the help of thermocouples placed on the plastification-injection cylinder. The HDPE samples were obtained at the following injection temperatures: $180,190,200,210$, and $220^{\circ} \mathrm{C}$. The PMMA samples were obtained at the following injection temperatures: $220,230,240,250$, and $260^{\circ} \mathrm{C}$, and the $\mathrm{PC}+\mathrm{ABS}$ samples were obtained at the following injection temperatures: $230,240,250,260$, and $270^{\circ} \mathrm{C}$. During the injection of the HDPE, PMMA and $P C+A B S$ specimens, all parameters that influence the cycles of injection were kept constant, altering only the processing temperatures. Injection of HDPE specimens was done by keeping the following injection parameters constant: subsequent pressure of $850 \mathrm{bar}$, mould temperature of $20^{\circ} \mathrm{C}$, cooling time of $10 \mathrm{~s}$, injection speed of $12 \mathrm{~mm} / \mathrm{s}$, and injection cycle of $44 \mathrm{~s}$. Injection of PMMA specimens was done by keeping the following injection parameters constant: subsequent pressure of $450 \mathrm{bar}$, mould temperature of $70^{\circ} \mathrm{C}$, cooling time of $12 \mathrm{~s}$, injection speed of $30 \mathrm{~mm} / \mathrm{s}$, and injection cycle of $35.8 \mathrm{~s}$. Injection of PC+ABS specimens was done by keeping the following injection parameters constant: subsequent pressure of 600 bar, mould temperature of $60^{\circ} \mathrm{C}$, cooling time of $10 \mathrm{~s}$, injection speed of $25 \mathrm{~mm} / \mathrm{s}$, and injection cycle of $30.8 \mathrm{~s}$.

The second part of the experiment focused on the influence of subsequent pressure on indentation hardness and on indentation modulus. The HDPE samples were obtained at the following subsequent pressures: 800,900 , 1000,1100 , and 1200 bar. The PMMA samples were obtained at the following subsequent pressures: 450, 550, 650,750 , and 850 bar, and the PC+ABS samples were obtained at the following subsequent pressures: 500,600 , 700,800 , and 900 bar. During the injection of the HDPE, PMMA and PC+ABS specimens, all parameters that influence the cycles of injection were kept constant, altering only the subsequent pressure. Injection of HDPE specimens was done by keeping the following injection parameters constant: injection temperature $220^{\circ} \mathrm{C}$, mould temperature of $20^{\circ} \mathrm{C}$, cooling time of $10 \mathrm{~s}$, injection speed of $12 \mathrm{~mm} / \mathrm{s}$, and injection cycle of $44 \mathrm{~s}$. Injection of PMMA specimens was done by keeping the following injection parameters constant: injection temperature $260^{\circ} \mathrm{C}$, mould temperature of $70^{\circ} \mathrm{C}$, cooling time of $12 \mathrm{~s}$, injection speed of $30 \mathrm{~mm} / \mathrm{s}$, and injection cycle of $35.8 \mathrm{~s}$. Injection of $P C+A B S$ specimens was done by keeping the following injection parameters constant: injection temperature $270^{\circ} \mathrm{C}$, mould temperature of $60^{\circ} \mathrm{C}$, cooling time of $10 \mathrm{~s}$, injection speed of $25 \mathrm{~mm} / \mathrm{s}$, and injection cycle of $30.8 \mathrm{~s}$.

All specimens were injected at S.C. Plastor S.A Oradea and underwent determinations regarding indentation hardness and indentation modulus within the precincts of the Laboratory of Advanced Materials of the University of Oradea (Advanced Materials Research Infrastructure SMARTMAT - www.erris.gov.ro). Determining the indentation hardness and indentation modulus was done on specimen models with the shape and size of those presented in figure 1 .

Testing was done in accordance with ISO 14577-1:2002 [24] using Agilent Technologies Nano Indenter G200 System equipment, USA, made in 2013, thorough the determination method of G-Series Basic Hardness, Modulus at a Depth.

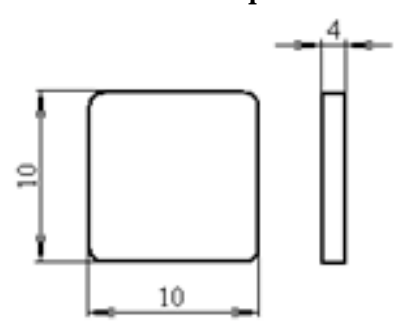

Fig.1 Specimen model for the testing of indentation hardness and indentation modulus

The specimen on the support undergoes indentation with the help of a pyramidal-shaped indenter with a triangular base, made of diamond, named the Berkovich tip (fig. 2).

Nanoindentation is a new and modern method of determining mechanical properties of materials of any kind at a very small scale. Nanoindentation is highlighted with the help of an atomic-force microscope by evaluating the area and depth of indentation. The tested area is then provided as an image to the atomic-force microscope for the determining of indentation hardness and indentation modulus. The force-movement variation graph obtained through indentation provides us with information on the mechanical and physical properties of the tested material. All tests were done at a temperature of $23^{\circ} \mathrm{C}$. Figure 3

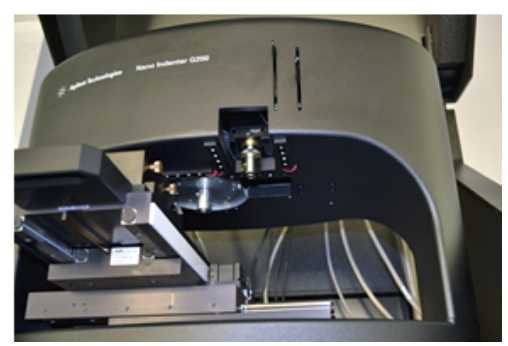

Fig.2 Berkovich indenter 


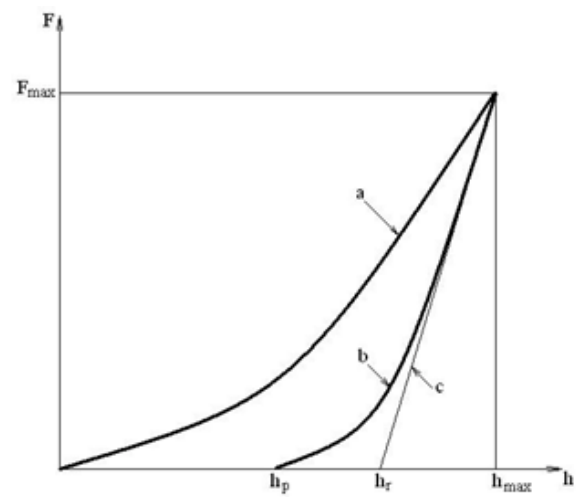

Fig.3 Schematic representation of test procedure: $a$ - application of the test force; $b$ - removal of the test force; $c$ - tangent to curve $b$ at $F_{\text {max }}$

sketches the testing procedure, and figure 4 sketches the transversal section of the indentation.

Determining the indentation hardness $\left(\mathrm{H}_{\mathrm{IT}}\right)$ is done using the equation (1):

$$
H_{I T}=\frac{F_{\max }}{A_{P}}, \quad\left[\mathrm{~N} / \mathrm{mm}^{2}\right]
$$

where:

$\mathrm{H}_{\text {IT }}$ - indentation hardness, in $\mathrm{N} / \mathrm{mm}^{2}$;

$\mathrm{H}_{\text {max }}^{\pi-}$ - maximum applied force, in $\mathrm{N}$;

$A p^{\max }$ the projection (transversal section) of the contact area between the indenter and tested specimen, resulted from the force-movement variation graph, in $\mathrm{mm}^{2}$.

In the case of the Berkovich indenter:

where:

$$
A_{p}=23.96 \times h_{c}^{2}
$$

$h$ is the depth made by indenter on the tested specimen, and it is calculated according to:

$$
h_{c}=h_{\max }-\varepsilon\left(h_{\max }-h_{k}\right)
$$

and $\varepsilon$ is a correcting factor depending on the indenter's geometry.

Determining the indentation modulus $\left(\mathrm{E}_{\mathrm{IT}}\right)$ is done using the equations ( 2 ) and (3):

$$
\begin{aligned}
E_{I T} & =\frac{1-\left(\mathrm{v}_{\mathrm{S}}\right)^{2}}{\frac{1}{E_{r}} \cdot \frac{1-\left(\mathrm{v}_{\mathrm{i}}\right)^{2}}{E_{i}}}, \quad\left[\mathrm{~N} / \mathrm{mm}^{2}\right] \\
E_{r} & =\frac{\sqrt{\pi}}{2 c \sqrt{A_{P}}}
\end{aligned}
$$

Fig.5 PMMA specimen tested by indentation

\section{Results and discussions}

The centralized results after the testing of HDPE samples concerning the influence of processing temperature on the indentation hardness, indentation modulus, and the maximum applied force are presented in table 1.

In figure 6 is graphically represented the variation of indentation hardness depending of the processing temperature in case of high-density polyethylene HDPE CABELEC XS6114.

\begin{tabular}{|c|c|c|c|}
\hline $\begin{array}{c}\text { Processing } \\
\text { temperature }\left[{ }^{\circ} \mathrm{C}\right]\end{array}$ & $\begin{array}{c}\text { Indentation } \\
\text { hardness [GPa] }\end{array}$ & $\begin{array}{c}\text { Indentation } \\
\text { modulus [GPa] }\end{array}$ & Maximum applied \\
\hline 180 & 0.038 & 0.831 & 3.784 \\
\hline 190 & 0.040 & 0.875 & 3.796 \\
\hline 200 & 0.040 & 0.929 & 3.890 \\
\hline 210 & 0.040 & 0.936 & 3.957 \\
\hline 220 & 0.042 & 0.941 & 4.078 \\
\hline
\end{tabular}

Table 1

INDENTATION HARDNESS, INDENTATION MODULUS, AND THE MAXIMUM FORCE APPLIED TO HDPE CABELEC XS6114 DEPENDING ON THE PROCESSING TEMPERATURE 


\section{HDPE}

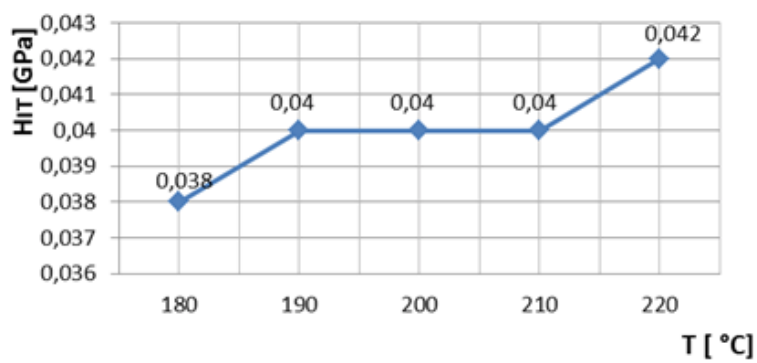

Fig. 6 The variation of indentation hardness depending of the processing temperature in case of HDPE CABELEC XS6114
PMMA

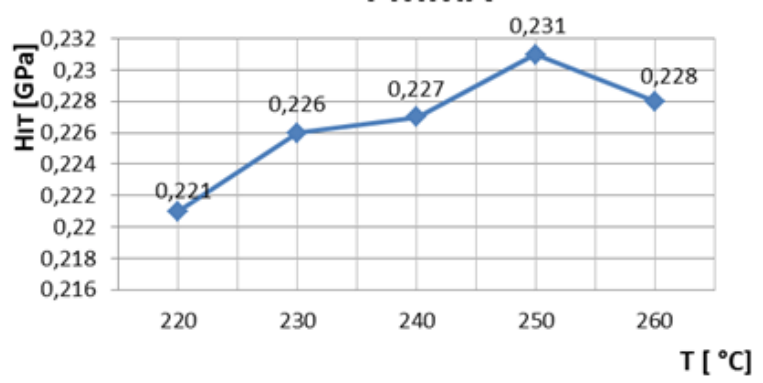

Fig.7 The variation of indentation hardness depending of the processing temperature in case of PMMA PLEXIGLAS 8N CRYSTAL.

\begin{tabular}{|c|c|c|c|}
\hline $\begin{array}{c}\text { Processing } \\
\text { temperature }\left[{ }^{\circ} \mathrm{C} \text { ] }\right.\end{array}$ & $\begin{array}{c}\text { Indentation } \\
\text { hardness [GPa] }\end{array}$ & $\begin{array}{c}\text { Indentation } \\
\text { modulus [GPa] }\end{array}$ & $\begin{array}{c}\text { Maximum applied } \\
\text { force }[\mathrm{mN}]\end{array}$ \\
\hline 220 & 0.221 & 4.665 & 21.448 \\
\hline 230 & 0.226 & 4.671 & 21.642 \\
\hline 240 & 0,227 & 4.678 & 21.686 \\
\hline 250 & 0.231 & 4.947 & 22.225 \\
\hline 260 & 0.228 & 4.876 & 21.906 \\
\hline
\end{tabular}

Table 2

INDENTATION HARDNESS, INDENTATION MODULUS, AND THE MAXIMUM FORCE APPLIED TO PMMA PLEXIGLAS 8N CRYSTAL DEPENDING ON THE PROCESSING TEMPERATURE
An increase in the processing temperature by injection of HDPE from 180 to $220^{\circ} \mathrm{C}$ leads to a slight increase in the indentation hardness, indentation modulus, and maximum applied force regarding the tested specimens. The maximum indentation hardness value of $0.042 \mathrm{GPa}$ was recorded at the temperature of $220^{\circ} \mathrm{C}$, and the maximum indentation modulus value of $0.941 \mathrm{GPa}$ was also recorded at $220^{\circ} \mathrm{C}$. The variation of the processing temperature by injection of HDPE CABELEC XS6114 has the same effect on both the indentation hardness and on the hardness resulted by penetration with a Shore type D Durometer [25], namely the increase in the processing temperature leads to an increase in the hardness of the tested specimens.

The centralized results after the testing of PMMA samples concerning the influence of processing temperature on the indentation hardness, indentation modulus, and the maximum applied force are presented in table 2.

In figure 7 is graphically represented the variation of indentation hardness depending of the processing temperature in case of methyl polymethacrylate, PMMA PLEXIGLAS 8N CRYSTAL.
It is observed that an increase in the processing temperature by injection of PMMA from 220 to $250^{\circ} \mathrm{C}$ leads to a slight increase in the indentation hardness. The maximum indentation hardness value of $0.231 \mathrm{GPa}$ was recorded at the temperature of $250^{\circ} \mathrm{C}$. A further increase in the processing temperature to $260^{\circ} \mathrm{C}$ leads to a decrease in indentation hardness to a value of $0.228 \mathrm{GPa}$. Similarly, the indentation modulus decreases due to the variation of the processing temperature by injection - the maximum value of $4.947 \mathrm{GPa}$ was recorded at $250^{\circ} \mathrm{C}$.

The centralized results after the testing of $P C+A B S$ blend samples concerning the influence of processing temperature on the indentation hardness, indentation modulus, and the maximum applied force are presented in table 3 .

In figure 8 is graphically represented the variation of indentation hardness depending of the processing temperature in case of mixture of polycarbonate acrylonitrile butadiene styrene type PC + ABS RESIN XCY620 CYCOLOY.

It is observed that an increase in the processing temperature by injection of $\mathrm{PC}+\mathrm{ABS}$ from 230 to $250^{\circ} \mathrm{C}$ leads to a slight increase in the indentation hardness and

\begin{tabular}{|c|c|c|c|}
\hline $\begin{array}{c}\text { Processing } \\
\text { temperature }\left[{ }^{\circ} \mathrm{C}\right]\end{array}$ & $\begin{array}{c}\text { Indentation } \\
\text { hardness [GPa] }\end{array}$ & $\begin{array}{c}\text { Indentation } \\
\text { modulus [GPa] }\end{array}$ & $\begin{array}{c}\text { Maximum applied } \\
\text { force [mN] }\end{array}$ \\
\hline 230 & 0.138 & 2.812 & 12.067 \\
\hline 240 & 0.146 & 2.911 & 12.620 \\
\hline 250 & $0^{\prime} 146$ & 2.915 & 12.635 \\
\hline 260 & 0.144 & 2.878 & 12.497 \\
\hline 270 & 0.143 & 2.870 & 12.416 \\
\hline
\end{tabular}

Table 3

INDENTATION HARDNESS, INDENTATION MODULUS, AND THE MAXIMUM FORCE APPLIED TO PC+ABS CYCOLOY RESIN XCY 620 DEPENDING ON THE PROCESSING TEMPERATURE 
PC+ABS

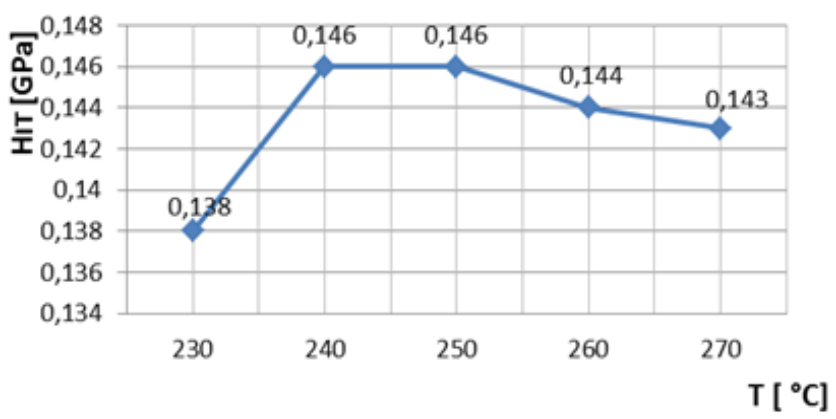

Fig. 8 The variation of indentation hardness depending of the processing temperature in case of $P C+A B S$ RESIN XCY620

\section{HDPE}

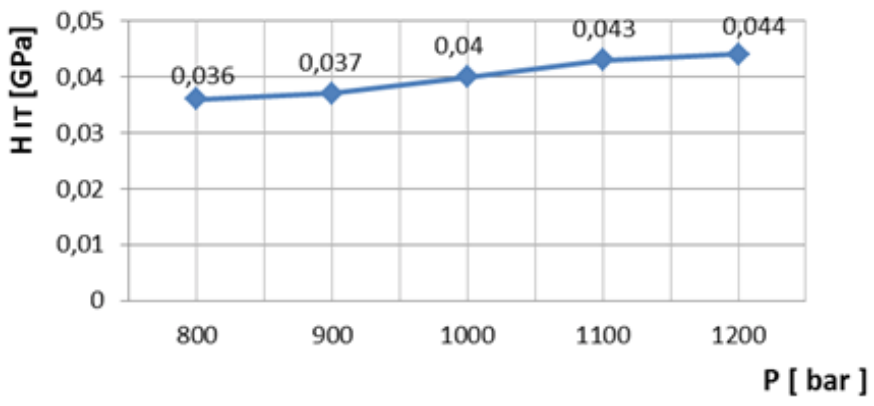

Fig.9 The variation of indentation hardness depending of the subsequent pressure in case of HDPE CABELEC XS6114 CYCOLOY.

\begin{tabular}{|c|c|c|c|}
\hline $\begin{array}{c}\text { Processing } \\
\text { temperature }\left[{ }^{\circ} \mathrm{C} \text { ] }\right.\end{array}$ & $\begin{array}{c}\text { Indentation } \\
\text { hardness [GPa] }\end{array}$ & $\begin{array}{c}\text { Indentation } \\
\text { modulus [GPa] }\end{array}$ & $\begin{array}{c}\text { Maximum applied } \\
\text { force [mN] }\end{array}$ \\
\hline 800 & 0.036 & 0.863 & 3.567 \\
\hline 900 & 0.037 & 0.880 & 3.689 \\
\hline 1000 & 0.040 & 0.941 & 3.913 \\
\hline 1100 & 0.043 & 0.960 & 4.078 \\
\hline 1200 & 0.044 & 0.980 & 4.189 \\
\hline
\end{tabular}

Table 4

INDENTATION HARDNESS, INDENTATION MODULUS, AND THE MAXIMUM FORCE APPLIED TO HDPE CABELEC XS6114 DEPENDING ON THE SUBSEQUENT PRESSURE indentation modulus. The maximum indentation hardness value of $0.146 \mathrm{GPa}$ for $\mathrm{PC}+\mathrm{ABS}$ was recorded at the temperature of $250^{\circ} \mathrm{C}$. The maximum indentation modulus value of $2.915 \mathrm{GPa}$ was recorded at the same temperature of $250^{\circ} \mathrm{C}$. A further increase in the processing temperature by injection leads to a decrease in indentation hardness and indentation modulus. It is observed that at the lowest processing temperature (HDPE - $180^{\circ} \mathrm{C}$, PMMA - $220^{\circ} \mathrm{C}$, and $P C+A B S-230^{\circ} \mathrm{C}$ ) when in the plastification-injection cylinder there is mechanical degradation, in the case of the three tested polymers, the lowest values of indentation hardness and indentation modulus are recorded. At the highest processing temperatures (HDPE - $220^{\circ} \mathrm{C}$, PMMA $260^{\circ} \mathrm{C}$, and $\mathrm{PC}+\mathrm{ABS}-270^{\circ} \mathrm{C}$ ) there is thermal degradation in PMMA and PC+ABS, which leads to a decrease in indentation hardness and indentation modulus. In the case of HDPE at $220^{\circ} \mathrm{C}$, the values of indentation hardness and indentation modulus are the highest, therefore at this temperature there is no thermal degradation.

The centralized results after the testing of HDPE samples concerning the influence of the subsequent pressure on the indentation hardness, indentation modulus, and the maximum applied force are presented in table 4.

In figure 9 is graphically represented the variation of indentation hardness depending of the subsequentpressure in case of high-density polyethylene HDPE CABELEC XS6114.

It is observed that an increase in the subsequent pressure of HDPE, from 800 bar to 1200 bar, leads to a slight increase in the indentation hardness and indentation modulus. The maximum indentation hardness value of 0.044 GPa for HDPE was recorded at the subsequent pressure of 1200 bar. The maximum indentation modulus value of $0.980 \mathrm{GPa}$ was recorded at the same subsequent pressure of 1200 bar.

The centralized results after the testing of PMMA samples concerning the influence of the subsequent pressure on the indentation hardness, indentation modulus, and the maximum applied force are presented in table 5.

In figure 10 is graphically represented the variation of indentation hardness depending of the subsequentpressure

\begin{tabular}{|c|c|c|c|}
\hline $\begin{array}{c}\text { Processing } \\
\text { temperature }\left[{ }^{\circ} \mathrm{C}\right]\end{array}$ & $\begin{array}{c}\text { Indentation hardness } \\
{[\mathrm{GPa}]}\end{array}$ & $\begin{array}{c}\text { Indentation modulus } \\
{[\mathrm{GPa}]}\end{array}$ & $\begin{array}{c}\text { Maximum applied } \\
\text { force }[\mathrm{mN}]\end{array}$ \\
\hline 450 & 0.228 & 4.876 & 21.906 \\
\hline 550 & 0.226 & 4.641 & 21.542 \\
\hline 650 & 0.225 & 4.640 & 21.442 \\
\hline 750 & 0.225 & 4.639 & 21.412 \\
\hline 850 & 0.224 & 4.620 & \\
\hline
\end{tabular}

Table 5

INDENTATION HARDNESS, INDENTATION MODULUS, AND THE MAXIMUM FORCE APPLIED TO PMMA PLEXIGLAS 8N CRYSTAL DEPENDING ON THE SUBSEQUENT PRESSURE 
PMMA

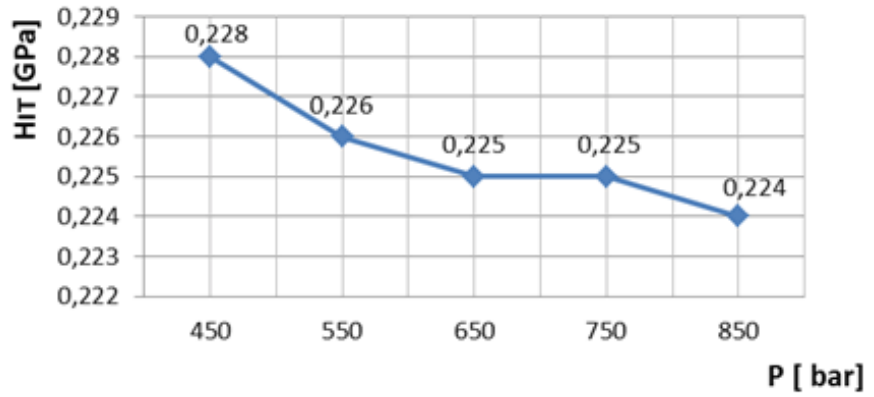

Fig.10. The variation of indentation hardness depending of the subsequent pressure in case of PMMA PLEXIGLAS 8N CRYSTAL.

\section{PC+ABS}

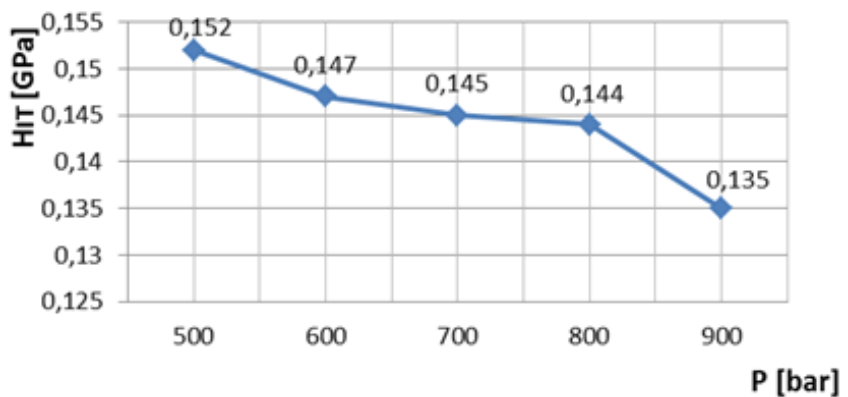

Fig.11. The variation of indentation hardness depending of the subsequent pressure in case of PC + ABS RESINXCY620CYCOLOY

\begin{tabular}{|c|c|c|c|}
\hline $\begin{array}{c}\text { Processing } \\
\text { temperature }\left[{ }^{\circ} \mathrm{C}\right]\end{array}$ & $\begin{array}{c}\text { Indentation } \\
\text { hardness [GPa] }\end{array}$ & $\begin{array}{c}\text { Indentation } \\
\text { modulus [GPa] }\end{array}$ & $\begin{array}{c}\text { Maximum applied } \\
\text { force [mN] }\end{array}$ \\
\hline 500 & 0.152 & 2.915 & 13.029 \\
\hline 600 & 0.147 & 2.900 & 12.716 \\
\hline 700 & 0.145 & 2.873 & 12.542 \\
\hline 800 & 0.144 & 2.866 & 12.528 \\
\hline 900 & 0.135 & 2.788 & 11.890 \\
\hline
\end{tabular}

Table 6

INDENTATION HARDNESS, INDENTATION MODULUS, AND THE MAXIMUM FORCE APPLIED TO PC+ABS CYCOLOY RESIN XCY620 DEPENDING ON THE SUBSEQUENT PRESSURE in case of methyl polymethacrylate, PMMA PLEXIGLAS 8N CRYSTAL.

It is observed that an increase in the subsequent pressure of PMMA, from 450 bar to 850 bar, leads to a slight decrease in indentation hardness and indentation modulus. For PMMA, the minimum indentation hardness value of $0.224 \mathrm{GPa}$ was recorded at a subsequent pressure of $850 \mathrm{bar}$, and the lowest indentation modulus value of 4.620 GPa was recorded at the same subsequent pressure of 850 bar.

The centralized results after the testing of $P C+A B S$ samples concerning the influence of the subsequent pressure on the indentation hardness, indentation modulus, and the maximum applied force are presented in table 6 .

In figure 11 is graphically represented the variation of indentation hardness depending of the subsequent pressure in case of mixture of polycarbonate acrylonitrile butadiene styrene type PC + ABS RESIN XCY620 CYCOLOY.

It is observed that an increase in the subsequent pressure of $P C+A B S$, from 500 bar to 900 bar, leads to a slight decrease in indentation hardness and indentation modulus. For $P C+A B S$, the minimum indentation hardness value of $0.135 \mathrm{GPa}$ was recorded at a subsequent pressure of $900 \mathrm{bar}$, and the lowest indentation modulus value of $2.788 \mathrm{GPa}$ was recorded at the same subsequent pressure of 900 bar. It is observed that an increase in the subsequent pressure in case of processing by injection of HDPE leads to a slight increase in the indentation hardness and in the indentation modulus, whereas in the case of PMMA and $P C+A B S$ blend an increase in the subsequent pressure leads to a decrease in the indentation hardness and in the indentation modulus of these two materials.

\section{Conclusions}

The first part of the paper researched the variation of indentation hardness and indentation modulus according to the processing temperature by injection, when other factors which could influence the process remain unchanged, for the high-density polyethylene HDPE CABELEC XS6114, polymethyl methacrylate PMMA PLEXIGLAS 8N CRYSTAL, and polycarbonate and acrylonitrile butadiene styrene blend PC+ABS CYCOLOY RESIN XCY620. The second part of the paper researched the variation of indentation hardness and indentation modulus according to the subsequent pressure by injection of HDPE, PMMA, and PC+ABS blend, when other factors which could influence the process remain unchanged. The HDPE samples were obtained at the following injection temperatures: $180,190,200,210$, and $220^{\circ} \mathrm{C}$, and at the following subsequent pressures: $800,900,1000,1100$, and 1200 bar. The PMMA samples were obtained at the following injection temperatures: $220,230,240,250$, and $260^{\circ} \mathrm{C}$, and at the following subsequent pressures: 450 , $550,650,750$, and 850 bar. The PC+ABS samples were obtained at the following injection temperatures: 230, 240, 250,260 , and $270^{\circ} \mathrm{C}$, and at the following subsequent pressures: 500, 600, 700, 800, and 900 bar. The specimens were injected with the help of a KRAUSS MAFFEI KM65$160 \mathrm{Cl}$ injection machine. Determining the indentation hardness and indentation modulus was done on model specimens in accordance with ISO 14577-1:2002 using Agilent Technologies Nano Indenter G200 System equipment, USA, made in 2013.

It was observed that by increasing the processing temperature and subsequent pressure, in the case of HDPE, leads to an increase in indentation hardness and in indentation modulus. It was observed that increasing the 
processing temperature by injection in the case of PMMA, from 220 to $250^{\circ} \mathrm{C}$, leads to a slight increase in indentation hardness and in indentation modulus, whereas increasing the subsequent pressure of PMMA, from 450 to 850 bar, leads to a slight decrease in indentation hardness and in the indentation modulus. Increasing the processing temperature by injection in the case of $\mathrm{PC}+\mathrm{ABS}$, from 230 to $250^{\circ} \mathrm{C}$, leads to a slight increase in indentation hardness and in indentation modulus. By further increasing the processing temperature by injection, from 250 to $270^{\circ} \mathrm{C}$, leads to a decrease in indentation hardness and in the indentation modulus.Alternatively, increasing the subsequent pressure from 500 to 900 bar leads to not only a decrease in indentation hardness but also to a decrease in the indentation modulus.

Acknowledgement: We offer our sincere appreciation to SC Plastor SA Oradea and SC Capirom SRL Santandrei for their material and logistic support towards the University of Oradea throughout the research, which focused on the influence that the processing temperatures by injection and the subsequent pressures by injection on the indentation hardness and on the indentation modulus, in the case of the three most frequently used techno-polymers in the manufacturing of technical items from various industries.

\section{References}

1. MARIES, GH., R., E., MANOVICIU, I., BANDUR, G., RUSU, G., PODE, V., Mat. Plast., 44, no.4, 2007, p.289.

2. MARIES, GH., R., E., Mat. Plast., 47, no.2, 2010, p.244.

3. NEDELCU, D., FETECAU, C., CIOFU, C., MINDRU, D., Mat. Plast., 46, no.3, 2009, p.269.

4. FETECAU, C., COSMA, L., STAN, F., Mat. Plast., 44, no.2, 2007, p.163. 5. POSTOLACHE, I., FETECAU, C., STAN F., NEDELCU, D., Mat. Plast., 46, no.4, 2009, p.458.

6. NEDELCU, D., MINDRU, D., FETECAU, C., COHAL, V., CRETU, G., Mat. Plast., 47, no.2, 2010, p.225.
7. SUAREZ, J., C., M., MANO, E., B., TAVARES M., I., B., J. Appl. Polym. Sci, 78, Issue: 4, 2000, p.899.

8. LI, B., ZHANG, XL., ZHANG, Q., CHEN, F., FU, Q., J. Appl. Polym. Sci, 113, Issue: 2, 2009, p.1207.

9. STAN, F., FETECAU, C., Mechanics of Time-Dependent Materials, 17, nr.2, 2013, p.205.

10. CURTU, I., MOTOC, D., L., Mat. Plast., 45, no.4, 2008, p.366.

11. STAN, F., Mat. Plast., 45, no.1, 2008, p.8.

12. LILE, I., E., FREIMAN, P., C., HOSSZU, T., VASCA, E., VASCA, V., BUNGAU, S., VAIDA, L., Mat. Plast., 52, no.2, 2015, p.175.

13. MANZUR, A., OLAYO, R., RAMOS, E., J. Appl. Polym. Sci, 65, Issue: 4, 1997, p.677.

14. SUAREZ, J.,C.,M., MANO, E., B., MONTEIRO, E., E., D., TAVARES, M., I., R., J. Appl. Polym. Sci, 85, Issue: 4, 2002, p.886.

15. MARSAVINA, L., CERNESCU, A., LINUL, E., SCURTU, D., CHIRITA, C., Mat. Plast., 47, no.1, 2010, p.85.

16. STAN, F., FETECAU, C., Composites Part B: Engineering, 47, 2013, p.298.

17. MARIES, GH. R. E., CHIRA, D., Mat. Plast., 49, no.4, 2012, p.288.

18. GURUPRASAD, B., RAGUPATHY, A., BADRINARAYANAN, T., S., VENKATESAN, R., IJET, 2, nr.12, 2012, p.1921.

19. VAIDA, L., MOLDOVAN, L., LILE, I., E., TODOR, B., I., PORUMB, A., TIG, I., BRATU, D., C., Mat. Plast., 52, no.3, 2015, p.364.

20. RADULESCU, R., BADILA, A., MANOLESCU, R., J APIE, I., BADILA, E., BOLOCAN, A., Mat. Plast., 50, no.3, 2013, p.212.

21. BALOS, S., BALOS, T., SIDJANIN, L., MARKOVIC, D., PILIC, B., PAVLICEVIC, J., Mat. Plast., 48, no.2, 2011, p.127.

22. PICHON J., F., Injection des matieres plastiques, Dunod, Paris, 2001, p.66.

23. TIMAR, J., COFARU, C., STANCIU, M., D., CURTU, I., FLOREA, D., COVACIU, D., Mat. Plast., 50, no.3, 2013, p.183.

24. *** ISO 14577-1:2002, Metallic materials - Instrumented indentation test for hardness and materials parameters - Part 1: Test method.

25. MARIES, GH., R., E., CHIRA, D., BUNGAU, C., Mat. Plast., 52, no.4, 2015, p.452.

26. CHIRA, D., MARIES, GH., R., E., BUNGAU, C., Mat. Plast., 52, no.4, 2015, p.572.

Manuscript received: 11.12 .2016 